\section{Expression Of The Classical Poetic Tradition Modern Poetry}

\author{
Ernazrova Gulbahor Isakovna \\ Samarkand State University, Uzbekistan
}

\author{
G OPEN ACCESS \\ The American Journal of \\ Social Science And \\ Education Innovations \\ JULY 2020 \\ Page No.: 153-162 \\ Volume-II Issue-VII \\ PUBLISHED: 30 JULY 2020 \\ www.usajournalshub.com/inde \\ x.php/tajssei \\ Copyright: Original content \\ from this work may be used \\ under the terms of the \\ Creative Commons Attribution \\ 4.0 licence.
}

\title{
Abstract
}

On the eve of independence and the decades that followed, Uzbek poetry was characterized by genre diversity, stylistic originality, poetic ideas and diversity of expression. One of the most characteristic features of the poetry of this period is the emergence of works in the spirit and tone of mysticism in the works of nomadic poets. We know from history that mysticism is a doctrine that has had a profound impact on the social, cultural, philosophical and literary life of the Uzbek people. Although a number of works on mysticism have been carried out in our literature, taking into account the lack of special research on the commonalities and differences of religious mysticism and philosophical-mystical views, in this article the expression of mystical traditions in our modern poetry Askar Mahkam, It is studied on the example of the work of Abduvali Qutbiddin.

Keywords: mysticism, mystical literature teachings, modernism, realism, tradition and innovation, socialist realism, style, religious mysticism, philosophical mysticism, , modern poetry

Materials and methods: In the article comparative, biografical, historical, structural methods were used effectively.

\section{Introduction.}

Looking at the history of literature, one can be sure that a certain doctrine, concept, method, direction, current of human society is doomed to increase, sometimes weaken, 
and sometimes completely forgotten. It is closely related to a number of issues, such as the scope of these methods of expression, the viability of their traditions, their art, their ideology, the importance of the demand for them. Just as romanticism is replaced by classicism, classicism by realism, realism by modernism, modernism by postmodernism, postmodernism by the literature of the globalization period, the currents, directions, doctrines within them are sometimes seen as predominant, sometimes as passive literary methods. discarded. However, it should be noted that a nation's literature, although under the influence of various "isms" at different times, can not be completely detached from its national, traditional roots. This nationalism, this tradition, in one way or another manifests itself in the literature of the post-Soviet period. This diversity is especially evident in Uzbek literature of the early twentieth century.

At the beginning of the last century, after centuries of feudal rule, the life of the peoples of Turkestan, which had fallen into decline, came into conflict with the unprecedented development of the world. During this period, various modernist movements such as surrealism, avant-garde, dadaism, imaginism, and futurism emerged as echoes of socio-political life in a number of developed countries of Europe. Abdulhamid Cholpon described the situation as follows: "The young man from the East, who is caught between the old and the new literature, is in a real dilemma. Old literature is sweet, new is sweet, and Western literature is sweet again. Which one should I give more? Sweeter than each other! "[ 13, p. 56]

Jadid literature is literature that has come to the fore at the crossroads of tradition and innovation. In fact, in addition to Jadid writers, religious literature and palace literature (in the Emirate of Bukhara) also functioned during this period [ 5, p. 7]. Jadid literature is a transitional literature that emerged in the history of our national literature, where classical and modern literature came into being. Its novelty, innovation, originality - although there is a certain influence of Western literature, it is from the heart of classical literature.

Creativity is a complex process that takes place in the psyche. This effect permeates the artist's heart, becomes his or her own nature, and manifests itself in a form that is difficult to perceive with the naked eye. In studying the influence of mystical philosophy in modern poetry, it is necessary to pay attention to these aspects of the issue.

\section{The main part.}

On the eve of independence and the following decades, Uzbek poetry is reminiscent of the literary process of the Jadid period, with its genre diversity, stylistic originality, diversity of poetic ideas and expressions, and other features. One of the most characteristic features of the literature of this period is the appearance of works in the spirit and tone of mysticism in most of the poets, young and old.

It is noteworthy that in the works of Askar Mahkam, Abduvali Qutbiddin, Aziz Said, Eshqobil Shukur, Abduvahid Hayit, Halima Ahmedova, Zebo Mirzo, who entered the literature in the $80 \mathrm{~s}$, the classical spirit is expressed in modern forms. In their work, they moved away from vague social themes, focused on the heart, and began to create "conditionally pure lyricism." We don't see any classical genres in their work. In general, it would be more accurate to call the genres of twentieth-century Uzbek poetry, in Jamal Kamal's words, "universal poems." Figuratively speaking, the western form is combined 
with the eastern content. The poetry of the pre-independence and post-independence period shifted from the "collective self" to the individual "I". Naturally, this process strengthened the status of the classical essence in poetry, created diversity, compositional and stylistic diversity in poetic genres and forms.

As long as there is a human society, there must be no ideological gap. The sociopolitical situation of the 1980s showed that the ideological vacuum was fragile and entrenched in the beliefs, atheistic ideas, poetic and ideological views that had been believed for decades. As a result, for some time, poems in the spirit of journalistic appeal also appeared, and he gradually gave way to the poetry of the heart. In poetry, mystical tones began to appear, first of all, in the form of images. By addressing the image of the prophets, governors, saints, thinkers, Sufi poets, the poets lived to strengthen the people's sense of faith, to understand the national identity, to receive support from the spirit of the great ancestors. watts. Instead of the doctrines of social realism based on class struggle, the idea of the struggle against lust, which is characteristic of classical poetry, continued to assert itself in poetry. This feature has become especially pathetic in the poetry of Askar Mahkam and Abduvali Qutbiddin.

When you look at the works of these two artists, you can see that the mystical tone is not the same in their poetry. It can be seen that this spirit was manifested in the religious-mystical form in Askar Mahkam and in the philosophical-mystical form in Abduvali Qutbiddin. Although a great deal of work has been done on mysticism in our literature, there is a need to identify their specific features and characteristics, given the lack of specific research on the commonalities and differences between religious mysticism and philosophical-mystical views.

Sheikh Muhammad Sodiq Muhammad Yusuf focuses on the role of mysticism in his book, The Imagination of Sufism. He states that Sufism is an "inner jurisprudence" and explains the difference between a jurist and a mystic as follows: "A jurist who teaches ablution should wash his hands thoroughly three times and analyze them by inserting his fingers between them. This is what you should do when you wash your face, and this is what you should do when you wash your feet."

The mystic who teaches ablution teaches how to hold the heart when one begins to perform this prayer and in the process of performing it. He describes in detail what should go through the heart when he washes each member. " [ 14, p. 66-67]

Simply put, if the verses and hadiths and the science of apparent jurisprudence, the Shari'ah, explain the apparent aspects of prayers such as ablution, ghusl, fasting, zakat, and hajj, then how to keep the heart in the course of these prayers is good and sad. how to pay, etc., is explained by the inner science of jurisprudence.

In the religious literature on mysticism, mysticism is not only about understanding the meanings of the Qur'an and the Sunnah, but also about understanding their essence and following them with the whole body. It also explains how a Muslim should treat concepts such as "heart," "soul," "mind," and "greed" which is a more complex process than understanding and distinguishing between them. In general, it is repeatedly stated in religious and mystical views that it is not permissible to follow the path of the sect without the Shari'ah.

Literary critic Najmiddin Kamilov, in support of the above views, defines philosophical mysticism as follows: "Sufi religious belief is a declaration of divine love as 
an emotional-intellectual doctrine in the combination of wisdom (philosophy), artistic creation." [1, p. 5]

According to the author, in mysticism, the power of reason and wisdom, as well as the immersion in emotion, the hot creative flight, the ritual, along with the established moral rules, is also an expression of a sense of freedom that ignores these same rules. along with the hidden mystery, there is also the open logical-philosophical observation.

"One side of mysticism is mysticism and the other is asceticism. But at the heart of it is the idea of pantsism - unity, writes the literary critic I. Haqqul. "That is why the cooperation of historians, theologians, philosophers, literary critics and psychologists is very important in the study of mysticism." [ 9, p. 3]

However, some mystical literature suggests that the theory of oneness is more acceptable than the theory of oneness: "Thus, there are three views on the theory of oneness.

1. Fully support the theory of Vahdatul. To know it as truth and enlightenment.

2. Complete denial of the theory of Vahdatul existence.

3. Introducing the theory of oneness instead of the theory of oneness.

However, a prominent figure in the Naqshbandi sect, the great scholar and Sufi Imam Rabbani (971-1034 hijri and 1563-1625 AD) added a fourth way to this view.

According to him, unity is a state of being taxed. Then everything that appears to a Sufi becomes one being. But as long as the tax is accompanied by divine guidance and prophetic guidance, it attains a different status. This status is superior to the status of Wahdatul Wujud and is called Vahdatush-Shuhud. The testimony of the tax that has reached the level of oneness is only that of the obligatory being (Allah). Because just as the stars disappear when the sun rises, so when you reach Allah, everything else becomes invisible.

Thus, due to Imam Rabbani, the differences and inconveniences caused by the unity of the people were eliminated, and no one was offended and returned to the state of the Muslim Republic, the Qur'an and the Sunnah, and the Islamic Shari'ah." [14, p. 240241]

Sufism reflects a number of complexities and contradictions. In order to understand it correctly and to use it as much as possible, the literary scholar Ibrahim Haqqul emphasizes the need to study mysticism in several separate directions: "The first of them is the history of Sufism. Although in general, without knowing this history, it is possible to put forward or conjecture convincing ideas about the reasons for the birth of mysticism, the contradictions in the process of formation and development, the early Sufi sects and the principles of mysticism in the post-unity period. it is very difficult to avoid saying.

The second is the practice of mysticism, in which one is interested in an institution that reflects the practice of Sufism, the sect. From today's point of view, the sect has already lived its life as an education system. It is unthinkable to resurrect him in previous forms. But it can also be used to purify morals, to perfect the spirit and the soul, and to solve problems in the spiritual life. At the same time, the murid or the Taliban must surrender completely to the will of the sheikh, go from door to door begging for food, like the Sufis who are condemned as lesser Sufis. deliberate withdrawal from the working people, speculation, dancing and self-denial have completely lost their significance not only for today, but also for the future. 
The third part is mystical literature. The connection of mysticism with fiction is much deeper and more extensive than that of art, philosophy, and music. However, the literature that is mobilized to propagate mystical ideas, laws, meanings, concepts, and truths, that is, the literature of Zuhd, the mystical "layer" that occupies a place in the classical literature of the East, is the same thing. it's not a creative phenomenon. " [ 11 , p. 31]

In the study of the manifestation of mystical traditions in modern poetry, we see that the signs of the three directions mentioned by the literary critic Ibrahim Haqqul are mixed. For example, Abdulla Aripov's poems included in the "Book of Hajj" series are in harmony with the hadiths of the Prophet, while Askar Mahkam's poems, especially in his epics, combine religious-mystical and philosophical-mystical experiences and views. In Qutbiddin's poetry, however, it can be observed that mystical philosophy is expressed in modern forms. The concepts of dreams, fantasies, pleasures, and inspirations, which are important in Sufi literature in expressing the state of Sufism or love, form the core of the poetry of Abduvali Qutbiddin's poetry.

Askar Mahkam is one of the poets who tried to introduce the philosophy of mysticism into modern Uzbek poetry in all its fullness and achieved some positive and creative results in this regard.

Academician Sayyid Nematullah Ibrahim, in his 1998 article on the work of Askar Mahkam, entitled The Sounds of the Soul, states: The migration of light means constant awareness, constant vigilance. At this stage of Askar Mahkam's research, the great masters of Muslim literature, Fariduddin Attar, Jalaliddin Rumi, and Muhammad Iqbal, became spiritual students. The divine light in the words of these three scholars shone in his heart, which was suspended in the struggle for worldly knowledge and philosophy.

In particular, the respectful study of the sacred works of Jalaliddin Rumi for decades has created in the poet's heart the need to master the science of the Holy Qur'an and Hadith. For almost a decade, Askar Mahkam has been constantly studying the interpretation of the Qur'an and the science of Hadith. Because the secret that leads a person to the heights of spiritual and spiritual perfection is in the Qur'an. Hadith Sharif is the most perfect human science. " [ 8, p. 7]

Most of Askar Mahkam's poems from the "Truth" selection, such as "Tavajjuh", "Love", and "Four Dervishes", show that modern poetry is saturated with mystical content. In these works, the feelings and emotions of the heart begin to cover the most characteristic and necessary lines in the process of the gradual development of lyrical expression.

... Gado said - Death is the capital of love

capital

capital

Gado said, "Death is the neighbor of love."

neighbor

neighbor

Gado said, "Death is the threshold of love."

threshold

threshold

Gado said, "Death is the room of love." 
Gado said

Stop Gado Stop Gado Stop Gado... [4, p. 316-317]

This poetic passage from the epic "Love" reveals the lyrical hero's way of perceiving and expressing the world, his mystical and philosophical worldview. It is not difficult to see the closeness and harmony of his approach to the concepts of "Death" and "Love" - the interpretation of the same issues by his predecessors - mystics.

"Looking at the essence of today's events from a mystical point of view has created new opportunities for the poet's style of expression," writes literary critic Shavkat Hasanov about the epics of Askar Mahkam. "The content of Askar Mahkam's epics determines the interpretation of spiritual issues in the new forms of the traditional genre, the predominance of the tone of the call to spiritual awakening, and the peculiarities of the principles of observation on a universal scale." [ 12, p. 31]

Askar Mahkam's epic "Tavajjuh" is dedicated to the sorrows of the king and poet Zahriddin Muhammad Babur. Although the work itself is a king, it sounds like the appeal of the dervish Babur, the slave of destiny, to the non-existence, to the Creator, to destiny, and to his own reproach:

The lunar eclipses,

Earrings are a coffin on the clouds.

Rivers are dying at the bottom,

The leaves are covered with lead.

The reed swarms are like an army,

It doesn't bleed forever.

Tears streamed down my face

The writing of the Tikis is death ... [ 4, p. 219]

In Babur's case, the synthesis of philosophical thinking about the events of life and the confusion and tragedy of human relations required, in essence, a philosophical poetic view of the world and man. It's as if we see celestial stains, coffins sliding across the clouds, dead rivers, the surface of a river like lead armor.

There are a number of aspects that bring modernist literature closer to mysticism. One of them is the same for both of them - the way of depicting the psyche of the protagonist in a very difficult and dramatic situation. All visual aids are aimed at revealing the tragedy in this situation. Therefore, in the above verse, the reed is not just a reed, it is the residence of an army facing death, its destiny sings its daily song with its own blood, the body of the soldiers is wet with tears, and the fate of these creatures is written. - death is watching.

Sayyid Nematullah Ibrahim writes that the poet's sense of humor inspired him to write the poem "Four Dervishes". - The story is one of the unique works of Askar Mahkam. At the end of the twentieth century, the poet understood the world from the point of view of religion. Only piety, only love, thinks of the dervishes who have attained the truth. [ 8 , p. 12]

In this poetic story, Askar Mahkam adheres to the traditions of folk storytelling and develops the subject of the work in both prose and poetry.

The lyrical protagonist of Askar Mahkam is reminiscent of Sufis and dervishes who have come down to us from the past. The following ghazal, written in the style of Darwish dhikr, is an example of this. 
Did you come, did you come Devona who wanted the truth

Did you come, did you come Devona who wanted the truth

Like steam in Bukhara, like wind in Samarkand

Did you reach Haq wanted Devona

The stars are falling on Kachkulin

Did you pick Haq wants Devona

When the souls come wanting a soul, they want a sacrifice

Did you givem Did Devon want the truth

Naqshbandi Mawlawi or Chishtiy or Bihishtiy

Were you, were you Haq wants Devona

When the kings shake hands and eat my bread

Are you here? Are you here?

Mansur caught the first deal in "Anal Haq"

Did you say Ho did Devona who wanted the truth

From Bukhara, from Baghdad, from Khatlon, from Khorasan

Have you come, have you come Devona who wants the truth

A mood, a mood-inspired folk song, apparently does not use any punctuation. Such poems are also found in the works of Fakhriyor. It seemed to us that the poets were trying to bring their poetry closer to the style of speech. The punctuation used today is in the Russian alphabet. Until then, punctuation was not used in Uzbek literature based on the Arabic alphabet. Perhaps these aspects of the issue need to be addressed.

In mysticism, the transition from one form to another is thought to have taken place first as a mineral, then as a plant, then as an animal, and then as a human being. We see various interpretations of this issue in a number of Askar Mahkam's poems;

In the poem, which begins, "A raven sits at the gate," we read:

It's all there - wolf thieves

And the house is full of ants

... It's human, though

Then man becomes an animal [ 4, p. 351]

While the poem depicts the paths of progress and perfection as if they were going backwards, and a strong poetic conclusion is drawn, the poem "Souls Gone" laments with pain that the process of human transformation is stuck in the middle:

The spirits are gone...

Kingdom - this is the body...

They are the corpses of infinite beings

These are not Adam yet 
Great New Year Gangs... [4, p. 391]

It is known that classical Eastern poetry has always had a figurative way of thinking based on gestures, symbols, metaphors, and we see the same features in the poetry of Abduvali Qutbiddin. Abduvali Qutbiddin has a core concept, ie base points, which gives a flight to the poetic idea, gradually improves his figurative way of thinking, defines the barrier and style of poetry, and these are imagination, imagination, memory, dreams, fairy-tale mysteries, moods. unconscious appearances. Whenever you look at a poem, it all grows out of these basic expressions.

Zarzin sarpolarda state fuzun,

Bread and salt to my heart,

Oh my love

Sim-sim-ey, sim-sim.

If I lie, my hands will break.

Childhood miserable in fiery wishes,

Receipt writes in the name of love.

If I live like a swallow,

The tulip is my mother

Sim-sim-ey, sim-sim.

If I cheat, my hands will break...

Like many of Abduvali Qutbiddin's poems, this poem "Oath" seems to be a fairy tale full of myths of the legendary soul. In "A Thousand and One Nights", "Ali Bobo and the Forty Thieves", the protagonist opens the door to the treasures with a "sim-sim" spell, and the lyrical protagonist of this poem wants to enter the treasury of his heart with that spell. There are no nude lines in the poem. Each line is aimed at revealing the enchanted world of the soul in love with its quality, analogy and harmony.

I said desert behind me, and I saw Badakhshan,

Like an old coin, five.

If I look for myself, I don't have a target,

Al-Omon, where am I,

Sim-sim-ey, sim-sim.

If I lie, my hands will break.

Oh my gosh

May I ask for your magic eyes,

Eh, wow, if I cut my throat, nay

Sim-sim-ey, sim-sim.

If I cheat, my heart will break. [3, p. 18]

Words, adjectives, phrases, terms, analogies, including "desert", "ancient coin", "if I look for myself", "no sign from me", "al-aman", "sim -sim-ey, sim-sim "- all shine like pearls selected from the property of folk epics and fairy tales, leading the reader from the real world to the romantic world.

From the point of view of logic, there is a vital illogicality in the last verse: "Oh, if I 
cut my throat, I will blow, // If I blow, it will burn.// Sim-sim-ey, sim-sim". By the logic of life, no one can puff with a cut throat, of course. But that's not the logic of art, of literature, of anything that can be figurative. Art is the art of creating logic out of nonsense. Therefore, the last verses are not a protest in the poem, but a delight.

I remembered you on the night of the dream,

A bird of happiness in your palm, a dove in your sail.

At the legs staring to you -

Deer...

It can happen in a fairy tale, in a fantasy, in a dream. Therefore, it would be more accurate to call the poet's poems in this spirit poetic spells. The "bird of fortune", the "dove", the "deer" are all images that come out of fairy tales. Emotions combine with these images in a nightmare to create a whole harmony.

We can see that the work of Abduvali Qutbiddin combines two principles, mysticism and modernism. Of course, it is more difficult to call a certain work pure Sufi or pure modern poetry, because in his poems these features are combined, they are seen as a kind of style.

The poet's work is a synthesis of different forms of expression, which gives rise to a unique original style. Of course, it should be noted that in this poetic style, mystical interpretations are at the forefront. It is, of course, a process closely related to the poet's family environment and upbringing. The poet's ancestors were already followers of mysticism.

Flora...

Animal world...

Bani adam dunyosi...

Three grains...

Three talots...

Three jokes...

Three poor graves...[ 2, p. 104]

To a person unfamiliar with mystical views, these lines may seem like mere phrases, fragmentary verses, and random sentences. However, according to the Sufi interpretation, the first verse deals with the history of the creation of mankind, the stages of maturity of the soul, and the second verse deals with the immortality of this world.

\section{Conclusion.}

In general, sociality, which had been a leading theme for decades in pre-independence and post-independence literature, has given way to emotional poetry. This, in turn, expanded the scope of creative research and experimentation, resulting in the study and creative assimilation of mystical teachings, modernist traditions.

In the Uzbek poetry of the new period, mystical tones in the poetic perception of reality - symbols, symbolic images, philosophical interpretations of the world and man with all its complexities and contradictions, wisdom, examples, graces, blessed names and deeds of Sufis, moreover, lived in the language of gestures, firmly established in the poetics of modern poetry. 
Thus, in modern Uzbek poetry, classical traditions began to prevail, styles and expressions became more colorful, attitudes to the interpretation of the world and man changed, and poetic content was renewed with depth and originality.

\section{References}

1. Komilov N. Sufism. T .: "Movarounnahr" - "Uzbekistan", 2009. p.5.

2. Qutbiddin A. Happy year. T .: Literature and Art Publishing House, 1991. p.132.

3. Qutbiddin A. Bor. T .; Gulom Publishing House, 2011. p.104

4. Mahkam A. The truth. Dushanbe "Adab", 1998. p. 316-317.

5. Issues of national awakening and Uzbek philology. - T .: Universitet, 1993. p.7

6. Oripov A. Harmony of years. T .: Ghafur Ghulam Publishing House of Literature and Art, 1984. p. 460.

7. Petroshevskiy I. Islam in Iran in VII- XV centuries. Leningrad, 1966. -p.319.

8. Sayyid Nematullah Ibrahim. "Sangin sadolari ruhning" // Mahkam A. The truth. Dushanbe "Adab", 1998. p.12.

9. Haqqul I. Sufism and poetry. T .: Ghafur Ghulam Publishing and Printing Association, 1991. p. 184

10. Haqqul I. Sufism: history, essence and research requirements // Journal of Uzbek language and literature. 2017, No. 3. p. 31

11. Haqqul I. Oriental classical literature and creativity of Ghafur Ghulam // Journal of Uzbek language and literature. 2018 Issue 3, p.20-31.

12. Hasanov Sh. The composition and nature of the epic. A .: 2011, p.103.

13. Cholpon. Literature is rare. T .: Cholpon Publishing House, 1994. - p.56.

14. Sheikh Muhammad Sodiq Muhammad Yusuf. Imagination of Sufism. T .: "Hilol-Nashr", 2016. p.296.

15. Izzat Sultan. Literature. - Tashkent: Instructor, 2005, p. 15.

16. Timofeev L.I. Foundation of literary theory. - M., 1971, p. 356.

17. Hegel. Aesthetics. I 4-x t. - M.: Iskusstva, 1971, p. 460. 